\title{
Microwave Irradiation Synthesis and Breast Carcinoma of 6-ethoxy-2-(2-methoxy- benzylideneamino)benzothiazole and Its Metal Complexes
}

\author{
Ali M. Hassan ${ }^{1}$, Bassem H. Heakal ${ }^{2 *}$, Osama Soliman¹, K. Abdalla ${ }^{3}$ and Wael M. \\ Abo El-Ata ${ }^{4}$ \\ ${ }^{1}$ Chemistry Dept, Faculty of Science, Al-Azhar University, Nasr City,11884, Cairo, Egypt. \\ ${ }^{2}$ Research Laboratory, Cairo Oil Refining Company, Mostorod, Kaliobia, Egypt. \\ ${ }^{3}$ Physics Dept., Faculty of Science, Al-Azhar University, Nasr City, 11884, Cairo, Egypt. \\ ${ }^{4}$ Faculty of Medicine, Al-Azhar University, Domiate City, Egypt.
}

\begin{abstract}
$\mathbf{E}$ FFICIENT and clean synthesis of Schiff base as a new ligand, 6-ethoxy-2-(2-methoxy benzylideneamino)benzothiazole have been synthesized in equimolar reaction of 2-amino6-ethoxy-benzothiazole with 2-methoxy benzaldehyde using microwave technique. The prepared Schiff base was reacted with some transition metal ions $\mathrm{Ni}(\mathrm{II}) \mathrm{Cu}(\mathrm{II}), \mathrm{Pd}(\mathrm{II}), \mathrm{Ag}(\mathrm{I})$ and $\mathrm{Au}(\mathrm{III})$ in equimolar ratio (M:L, 1:1) using microwave technique. The stereochemistry and the bonding characteristics of the ligand and its complexes were achieved based on elemental analysis, FT-IR, UV-Vis., ${ }^{1} \mathrm{HNMR}$ and ESR as well as Thermo-Gravimetric Analysis (TGA). The thermal dehydration and decomposition of $\mathrm{Ni}(\mathrm{II}), \mathrm{Cu}(\mathrm{II})$ and $\mathrm{Ag}(\mathrm{I})$ complexes were studied kinetically using the integral method applying the Coats-Redfern and Horowitz Metzger equations. The reactivity of ligand and its $\mathrm{Au}(\mathrm{III})$ complex were studied against breast carcinoma cell. The antimicrobial activity of ligand and its $\mathrm{Ag}(\mathrm{I})$ complex studied against the bacterial (positive and negative) grams and fungal strains.
\end{abstract}

Keywords: Microwave synthesis, Breast cancer and Thermal analysis

\section{Introduction}

Microwave-assisted synthesis is a branch of green chemistry. Microwave irradiated reactions under solvent free or less solvent conditions are attractive offering reduced pollution, low cost and offer high yields together with simplicity in processing and handling. The salient features of microwave approach are shorter reaction times, simple reaction conditions and enhancements in yields $[1,2]$. Microwave heating has been widely used in organic and inorganic synthesis and Metal-Organic Frame works (MOFs) is well known [3]. However, it has not been less popular with the activation of coordination compounds [4]. Reports on the synthesis of metal complexes by microwave methods have been comparatively less. Different Schiff bases are prepared recently using benzothiazole/ benzothiazole-derivatives and appropriate carbonyl compounds $[5,6]$. These Schiff bases are of great interest because of their structural variety, varied denticities and subtle steric and/or electronic effects leading to complexes of different dimensionalities. Moreover, their ability to form non-covalent interactions likes hydrogen bonding interactions. In the 1950 s, a number of 2-aminobenzothiazoles were intensively studied as central muscle relaxants. Since then, biologist's attention was drawn to this series when pharmacological profile of Riluzole (6-trifluoormethoxy-2-benzothiazolamines, marketed as Rilutek), as a Glutamate neurotransmission inhibitor was discovered. After that benzothiazole derivatives have been extensively studied and found to have diverse chemical reactivity and broad spectrum of activity $[7,8]$. Benzothiazole derivatives are known to have wide spectrum of therapeutic activities such as: Antitumor activity [9-11], Antibacterial

*Corresponding author e-mail: waelsfy@gmail.com

DOI: 10.21608/ejchem.2018.4444.1401

(C) 2017 National Information and Documentation Centre (NIDOC) 
and antifungal activity $[12,13]$, Antihelmintic activity $[14,15]$, Antiviral activity [16], Antimalarial activity [17], Antileishmanial, Antischistosomicidal activity [18], AntiInflammatory activity $[19,20]$, Anticonvulsant activity $[21,22]$ and Anti-Diabetic activity $[23,24]$. Various investigations have proved that binding of a drug to metallo elements enhances its activity and, in some cases, the complex possesses even more healing properties than the parent drug [25]. In the present study metal ions of nickel (II), copper(II), palladium(II), silver(I) and gold(III) have been focused due to their smaller size and comparatively higher nuclear charge and thus have a great affinity to form coordination compounds with 6-ethoxy-2-(2methoxy benzylideneamino) benzothiazole as a novel Schiff base of benzothiazole-derivatives.

\section{Experimental}

\section{Material and methods}

All chemicals used were of annular grade. Microwave assisted reactions were carried out in a domestic microwave energy output 900 $\mathrm{W}$, frequency $2450 \mathrm{MHz}$, manufactured by DAEWOO technologies corporation, model: KOR-9G2B, Korea and the microwave reactions were performed using on/off cycling to control the temperature, the reactions were monitored by thin layer chromatography (TLC) with Merck percolated silica plates. Melting points were recorded in open capillaries on Thiel's tube melting point apparatus and are uncorrected. The UV-vis range (200-900 nm) using Perkin Elmer Lambda $35 \mathrm{UV} / \mathrm{Vis}$ spectrometer at Al-Azhar University. The Fourier transform infrared spectra with the samples dissolved in $\mathrm{KBr}$ were recorded on Vertex 70 Analyzer, Bruker, USA from $400-4000 \mathrm{~cm}^{-1}$ and magnetic susceptibility of prepared complexes were carried out at Mansoura University, Cairo, Egypt. The ESR spectra of the powdered $\mathrm{Cu}(\mathrm{II})$ complex was carried out on Bruker-EMX-(Xbands-9.7 GHZ) spectrometer with $100 \mathrm{KHz}$ frequency, microwave power $1.008 \mathrm{MW}$, modulation/amplitude of 4 Gauss and thermal analysis measurements were carried out on Shimadzu TGA spectrophotometer at National Center for Radiation Research and Technology, Egyptian Atomic Energy. The C, H and $\mathrm{N}$ analysis are carried out using a Flash 2000 organic Elemental Analyzer, Thermo, USA at the Main Chemical Warfare Laboratories, Ministry of Defense, Cairo, Egypt. The ${ }^{1} \mathrm{HNMR}$ spectra were recorded at Cairo University, Cairo, Egypt.

Egypt. J. Chem. 62, No. 3 (2019)
Using Agilent NMR400 MHz spectrometer at $300 \mathrm{MHz}$ in dimethylsulphoxide (DMSO-d6), tetramethysilane (TMS) was used as an internal reference and chemical shifts are quoted in $\delta(\mathrm{ppm})$. Mass spectra were performed by a Shimadzu-GCMS-QP1000 EX using the direct inlet system, Antitumor Evaluation, read the absorbance at 490 nm using ELISA reader (Sun Rise, TECAN, INC, USA) and antimicrobial activity were studied at Fermentation Biotechnology \& Application Microbiology (Ferm-BAM) Center, Al-Azhar University, Cairo, Egypt.

General procedure for synthesis of 6-ethoxy-2-(2methoxybenzylideneamino)benzothiazole Schiff base Ligand.

The equimolar (1:1) ratio of 2-amino-6ethoxy-benzothiazole $(1.942 \mathrm{~g}, 0.01 \mathrm{~mol})$ with 2-methoxy benzaldehyde (1.361 g, $0.01 \mathrm{~mol})$ was mixed thoroughly in a grinder. The reaction mixture was then irradiated by the microwave oven by taking drops of ethanol. The reaction was completed in 1.5-2.0 mins with high percentage yield (95\%), yellow product, with m.p. of 128 ${ }^{\circ} \mathrm{C}$. The resulting product was then recrystallized with ethanol and finally dried under reduced pressure over anhydrous $\mathrm{CaCl}_{2}$ in desiccators. The progress of the reaction and purity of the product was monitored by TLC using silica gel G.

6-ethoxy-2-(2-methoxybenzylideneamino) benzothiazole Schiff base Ligand

The prepared Schiff base is then characterized IR $\left(\mathrm{KBr}, \mathrm{cm}^{-1}\right): 1590 \quad(\mathrm{HC}=\mathrm{N}), 1223 \quad(\mathrm{C}-\mathrm{O}$ methoxy), $1554(\mathrm{C}=\mathrm{N}$, thiazole ring), 2990(C$\mathrm{H}$, aromatic), 2920(C-H, aliphatic). ${ }^{1} \mathrm{HNMR}$ (DMSO-d6, $\delta$, ppm) (Fig. 1): $1.35\left(\mathrm{t}, 3 \mathrm{H}, \mathrm{CH}_{3}\right.$ adjacent to $\mathrm{CH}_{2}$ ), $3.86\left(\mathrm{~s}, 3 \mathrm{H}, \mathrm{O}-\mathrm{CH}_{3}\right), 4.09$ (q, $2 \mathrm{H}, \mathrm{CH}_{2}$ adjacent to $\mathrm{CH}_{3}$ ), 7.04-8.03 (aromatic $\mathrm{C}-\mathrm{H}), 9.01(\mathrm{~s}, \quad 1 \mathrm{H}, \mathrm{CH}=\mathrm{N})$ [26], Elemental analysis; $\mathrm{C} \%$ (found $=58.01$, calc. $=57.69$ ), $\mathrm{H} \%$ (found $=5.18, \quad$ calc. $=5.16$ ), $\quad \mathrm{N} \% \quad$ (found $=8.92$, calc. $=8.97)$, Anal. Calcd. for $\left(\mathrm{C}_{17} \mathrm{H}_{16} \mathrm{O}_{2} \mathrm{~N}_{2} \mathrm{~S}\right.$, MWt. $=312.39),[\mathrm{M}]^{+}=312$.

General procedure for the synthesis of complexes

The ligand and the metal salts; $\mathrm{Ni}\left(\mathrm{CH}_{3} \mathrm{COO}\right)_{2} \cdot 4 \mathrm{H}_{2} \mathrm{O}, \mathrm{Cu}\left(\mathrm{CH}_{3} \mathrm{COO}\right)_{2} \cdot \mathrm{H}_{2} \mathrm{O}, \mathrm{PdCl}_{2}$, $\mathrm{AgNO}_{3}$ and $\mathrm{HAuCl}_{4}$ were mixed in $(1: 1)$ of (metal: ligand) ratio thoroughly in a grinder. The reaction mixtures were then irradiated by the microwave oven by taking drops of ethanol. The reaction was completed in 2-5 mins with high yields. The resulting product was then recrystallized with ethanol and ether and finally dried under reduced pressure over anhydrous $\mathrm{CaCl}_{2}$ in a desiccator. 
The progress of the reaction and purity of the product was monitored by TLC using silica gel $\mathrm{G}$. The same method was used for the preparation of all complexes (Scheme 1). Physical, analytical and spectral data are given in Tables 1 and 2.

\section{Biological assays \\ Antimicrobial evaluation}

The synthesized ligand and its $\operatorname{Ag}(\mathrm{I})$ complex were screened for their antimicrobial activity against six different test organisms having environmental and clinically importance the antimicrobial activity of synthesized compounds was determined using agar well diffusion method. The ligand and $\operatorname{Ag}(\mathrm{I})$ were tested in vitro for their antibacterial activity against staphylococcus aureus and Streptococcus mutans (Gram positive bacteria), Escherichia coli, Pseudomonas aeruginosa and klebsiella (Gram negative bacteria) and Candida albicans (Fungi) using nutrient agar medium. Ampicillin, Gentamicin and Nystatin were used as standard drugs for Gram positive, Gram negative and Fungi, respectively. DMSO was used as solvent control. The compounds were tested at a concentration of $15 \mathrm{mg} / \mathrm{ml}$ against both bacterial and fungal strains.

Disc diffusion method: The sterilized media was poured onto the sterilized Petri dishes (20$25 \mathrm{ml}$, each petri dish) and allowed to solidify at room temperature. Microbial suspension was prepared in sterilized saline equivalent to McFarland 0.5 standard solution (1.5x $105 \mathrm{CFU}$ $\mathrm{ml}^{-1}$ ) and its turbidity was adjusted to $\mathrm{OD}=0.13$ using spectrophotometer at $625 \mathrm{~nm}$. Optimally, within 15 minutes after adjusting the turbidity of the inoculum suspension, a sterile cotton swab was dipped into the adjusted suspension and was flooded on the dried agar surface then allowed to dry for 15 minutes with lid in place. Wells of $6 \mathrm{~mm}$ diameter was made in the solidified media with the help of sterile borer. $100 \mu$ of the solution of the tested compound was added to each well with the help of micropipette. The plates were incubated at $37^{\circ} \mathrm{C}$ for $24 \mathrm{hrs}$ in case of antibacterial and antifungal activity. This experiment was carried out in triplicate and zones of inhibition were measured in mm. scale [27].

\section{Antitumor assay}

Human breast cancer cell lines (MCF-7) cell lines were used for in vitro screening experiments. The cancer cells were obtained frozen from Vacsera Tissue Culture Unit, Cairo, Egypt and the experiments were carried out in Center of the fungus and its applications, Al-Azhar University.
The cells were propagated in Dulbecco's modified Eagles medium (DMEM) supplemented with $10 \%$ heat-inactivated fetal bovine serum, $1 \%$ L-glutamine, HEPES buffer and $50 \% 8 \mathrm{~g} / \mathrm{ml}$ gentamycin. All cells were maintained at $37{ }^{\circ} \mathrm{C}$ in humidified atmosphere with $5 \% \mathrm{CO}_{2}$ and sub cultured two times a week. Cells were seeded in 96-well plates at a cell concentration of $1 \times 10^{4}$ cell/well in $100 \mu \mathrm{l}$ of growth medium. Fresh medium containing different concentrations of the test sample was added after $24 \mathrm{~h}$ of seeding. Serial two-fold dilutions of the tested compounds were added to confluent cell monolayers dispensed into 96-well, flat-bottomed microtiter plates (Falcon, NJ, USA) using a multichannel pipette. The microtiter plates were incubated at $37{ }^{\circ} \mathrm{C}$ in a humidified incubator with $5 \% \mathrm{CO}_{2}$ for a period of $48 \mathrm{~h}$. Three wells were used for each concentration of the tested sample. Control cells were incubated without test sample and with or without DMSO. The little percentage of DMSO present in the wells (maximal $0.1 \%$ ) was found not to affect the experiment. After incubation of the cells for $24 \mathrm{hrs}$. at $37{ }^{\circ} \mathrm{C}$, Various concentrations of sample $(50,25,12.5,6.25,3.125$ and $1.56 \mu \mathrm{g})$ were added, and the incubation was continued for $48 \mathrm{hrs}$. and viable cells yield was determined by colorimetric method, growth inhibition of cells was calculated spectrophotometrically using a standard method with crystal violet solution (1\%) [12]. The optical density (OD) of each well was measured at $490 \mathrm{~nm}$ with an ELIZA, plate reader. Cisplatin (Sigma) was employed as the standard antitumor drug. The percentage of cell survival was calculated as follows:

Survival fraction $=$ OD $($ treated cells $) /$ OD (control cells)

The $\mathrm{IC}_{50}$ value is the concentration required to produce $50 \%$ inhibition of cell growth. The results are compared with a similar run of Cisplatin as an antitumor compound.

\section{Results and Discussion}

The Schiff base ligand was prepared by the condensation reaction of 2-methoxy benzaldehyde with 2-amino-6-ethoxy-benzothiazole under microwave irradiation as shown in Scheme 1. The synthesized Schiff base ligand was soluble in ethanol on heating only, while in dioxane, DMF and DMSO at room temperature. The structure of the ligand was established and reported elsewhere with the help of their IR, ${ }^{1} \mathrm{HNMR}$ and microanalytical data. The compound was used

Egypt. J. Chem. 62, No. 3 (2019) 
TABLE1. Analytical, physical and spectroscopic data of the ligand and its related complexes.

\begin{tabular}{|c|c|c|c|c|c|c|c|c|c|c|c|c|c|c|c|}
\hline \multirow{2}{*}{$\begin{array}{l}\text { Molecular } \\
\text { Formula }\end{array}$} & \multirow{2}{*}{ Symbol } & M.P & Yield & Time & \multirow{2}{*}{ Color } & \multicolumn{4}{|c|}{$\begin{array}{l}\text { Elemental Analysis } \\
\text { Calc. / (Found) \% }\end{array}$} & \multirow{2}{*}{$\begin{array}{c}\mathrm{M}^{+} \\
\text {Calc./ } \\
\text { (Found) }\end{array}$} & \multirow{2}{*}{$\mu_{\text {eff }}$} & \multirow{2}{*}{$\begin{array}{l}E_{s} \\
\text { (ev) }\end{array}$} & \multirow{2}{*}{$\begin{array}{c}\text { 'H-NMR } \\
\text { Chemical shift ( }(\mathbf{p p p m})\end{array}$} & \multicolumn{2}{|c|}{ ESR } \\
\hline & & C & $\%$ & $\min$ & & C & H & $\mathrm{N}$ & M & & & & & $\mathrm{g} \perp$ & $\mathrm{g} \|$ \\
\hline $\mathrm{C}_{17} \mathrm{H}_{16} \mathrm{~N}_{2} \mathrm{O}_{2} \mathrm{~S}$ & L & 128 & 97 & 3 & Yellow & $\begin{array}{l}57.69 \\
(58.01)\end{array}$ & $\begin{array}{l}5.16 \\
(5.18)\end{array}$ & $\begin{array}{l}8.97 \\
(8.92)\end{array}$ & - & $\begin{array}{l}312.39 \\
(312.0)\end{array}$ & & 2.8 & $\begin{array}{c}1.35\left(\mathrm{t}, 3 \mathrm{H}, \mathrm{CH}_{3} \text { adjacent to } \mathrm{CH}_{2}\right) \text {, } \\
3.86\left(\mathrm{~s}, 3 \mathrm{H}, \mathrm{O}-\mathrm{CH}_{3}\right), 4.09\left(\mathrm{q}, 2 \mathrm{H}, \mathrm{CH}_{2}\right. \\
\left.\text { adjacent to } \mathrm{CH}_{3}\right), 7.04-8.03 \text { (aromatic } \\
\quad \mathrm{C}-\mathrm{H}), 9.01(\mathrm{~s}, 1 \mathrm{H}, \mathrm{CH}=\mathrm{N})\end{array}$ & - & - \\
\hline $\begin{array}{c}{\left[\mathrm{Ni}(\mathrm{L})(\mathrm{AcO})_{2}\right] 3 \mathrm{H}_{2} \mathrm{O}} \\
\mathrm{NiC}_{21} \mathrm{H}_{28} \mathrm{~N}_{2} \mathrm{O}_{9} \mathrm{~S}\end{array}$ & 1 & 195 & 93 & 10 & $\begin{array}{l}\text { Yellowish } \\
\text { green }\end{array}$ & $\begin{array}{l}46.42 \\
(47.23)\end{array}$ & $\begin{array}{l}5.19 \\
(5.68)\end{array}$ & $\begin{array}{l}5.15 \\
(5.51)\end{array}$ & $\begin{array}{l}10.66 \\
(10.35)\end{array}$ & 543.22 & 3.0 & 2.6 & - & - & - \\
\hline $\begin{array}{c}{\left[\mathrm{Pd}_{2}(\mathrm{~L}) \mathrm{Cl}_{4}\right]} \\
\mathrm{Pd}_{2} \mathrm{C}_{17} \mathrm{H}_{16} \mathrm{Cl}_{4} \mathrm{~N}_{2} \mathrm{O}_{2} \mathrm{~S}\end{array}$ & 3 & 185 & 91 & 12 & Brick-red & $\begin{array}{l}30.6 \\
(30.32)\end{array}$ & $\begin{array}{l}2.42 \\
(2.29)\end{array}$ & $\begin{array}{c}4.2 \\
(4.53)\end{array}$ & $\begin{array}{l}29.59 \\
(29.02)\end{array}$ & 666.92 & $\mathrm{Di}$ & 2.4 & - & - & - \\
\hline $\begin{array}{c}{\left[\mathrm{Ag}(\mathrm{L}) \mathrm{NO}_{3}\right]} \\
\mathrm{AgC} \mathrm{C}_{17} \mathrm{H}_{16} \mathrm{~N}_{3} \mathrm{O}_{5} \mathrm{~S}\end{array}$ & 4 & $>300$ & 90 & 6 & $\begin{array}{l}\text { Yellowish } \\
\text { brown }\end{array}$ & $\begin{array}{l}42.16 \\
(42.68)\end{array}$ & $\begin{array}{l}3.33 \\
(4.02)\end{array}$ & $\begin{array}{l}8.68 \\
(8.99)\end{array}$ & $\begin{array}{l}22.37 \\
(22.75)\end{array}$ & 482.26 & $\mathrm{Di}$ & 2.4 & - & - & - \\
\hline $\begin{array}{c}{\left[\mathrm{Au}(\mathrm{L}) \mathrm{Cl}_{3} \mathrm{H}_{2} \mathrm{O}\right] 3 \mathrm{H}_{2} \mathrm{O}} \\
\mathrm{AuC}_{11} \mathrm{H}_{24} \mathrm{Cl}_{3} \mathrm{~N}_{2} \mathrm{O}_{6} \mathrm{~S}\end{array}$ & 5 & $>300$ & 95 & 15 & Brown & $\begin{array}{l}29.83 \\
(30.43)\end{array}$ & $\begin{array}{l}3.52 \\
(3.15)\end{array}$ & $\begin{array}{l}4.07 \\
(4.21)\end{array}$ & $\begin{array}{l}28.64 \\
(27.95)\end{array}$ & 687.80 & $\mathrm{Di}$ & 1.8 & - & - & - \\
\hline
\end{tabular}

TABLE 2. Significant FT-IR and electronic absorption data of the ligand and its metal complexes.

\begin{tabular}{|c|c|c|c|c|c|c|c|c|c|c|c|}
\hline Symbol & $\mathbf{v}\left(\mathrm{H}_{2} \mathrm{O}\right)$ & $\begin{array}{c}v(\mathrm{C}-\mathrm{H}) \\
\text { aromatic } \\
\text { aliphatic }\end{array}$ & $\begin{array}{c}v(C=N) \\
\text { azo } \\
\text { methane }\end{array}$ & $\begin{array}{l}v(\mathrm{C}=\mathrm{N}) \\
\text { benzo } \\
\text { thiazole }\end{array}$ & $\begin{array}{c}v(\mathbf{O A c}) \\
v_{\mathrm{as}} \\
\mathrm{v}_{\mathrm{s}}\end{array}$ & $v(C-O-C)$ & $v(M-N)$ & $v(\mathrm{M}-\mathrm{O})$ & $v(\mathrm{M}-\mathrm{Cl})$ & $\underset{\left(\mathrm{cm}^{-1}\right)}{\lambda_{\max }}$ & Assignment \\
\hline 2 & 3357 & $\begin{array}{l}2973 \\
2927\end{array}$ & 1567 & 1535 & $\begin{array}{l}1415 \\
1342\end{array}$ & 1211 & 511 & 430 & - & $\begin{array}{l}23585 \\
18450\end{array}$ & $\begin{array}{l}\text { LMCT } \\
{ }^{2} \mathrm{~B}_{2} \rightarrow{ }^{2} \mathrm{E}\end{array}$ \\
\hline 4 & - & $\begin{array}{l}2978 \\
2935\end{array}$ & 1596 & 1558 & - & 1221 & 515 & 428 & - & 24390 & MLCT \\
\hline 5 & 3375 & $\begin{array}{l}2979 \\
2915\end{array}$ & 1590 & 1546 & - & 1218 & 511 & 472 & 410 & 22448 & ${ }^{6} \mathrm{~A}_{\mathrm{lg}} \rightarrow{ }^{6} \mathrm{E}_{\mathrm{g}}$ \\
\hline
\end{tabular}




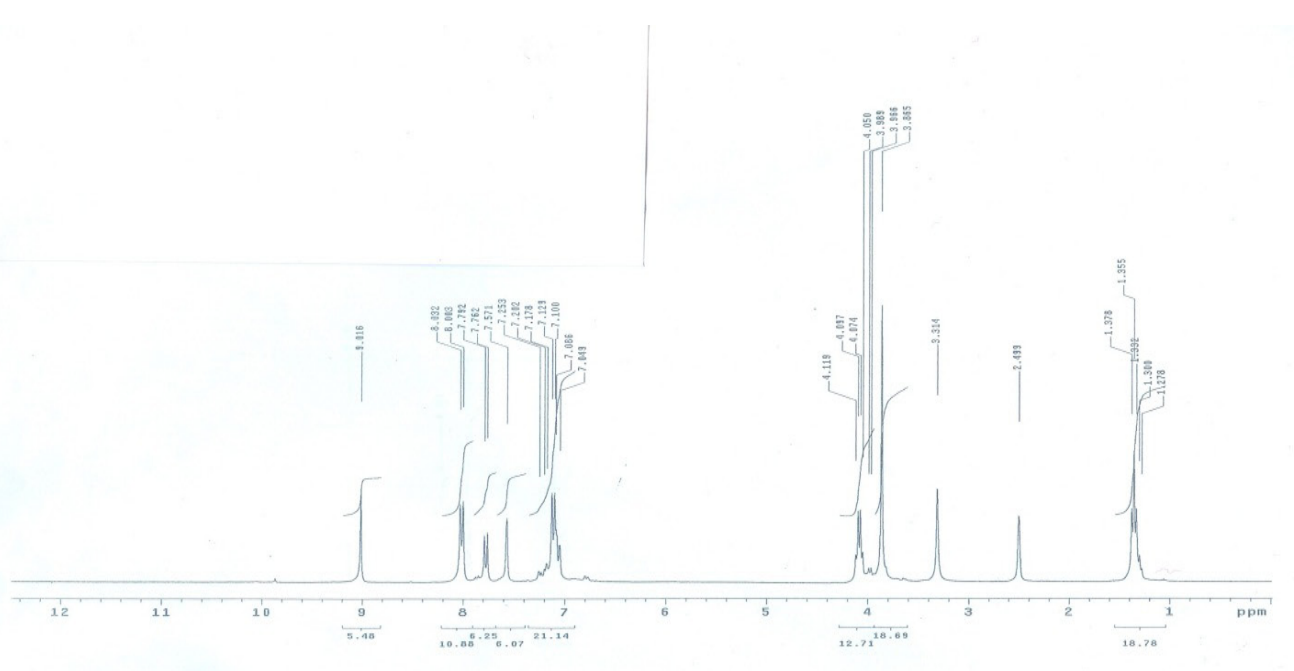

Fig. 1. 1HNMR Spectra of the Ligand.

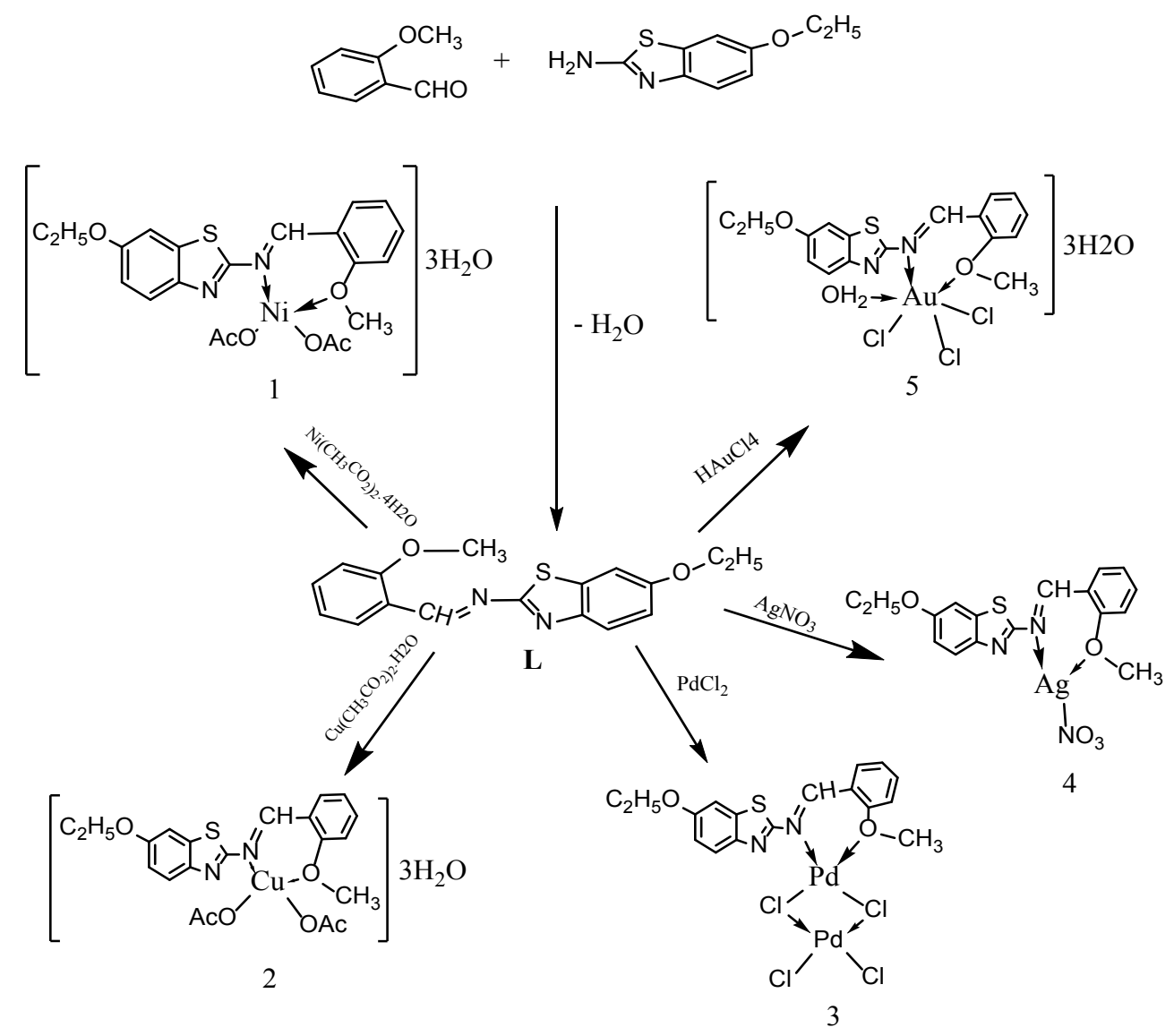

Scheme 1. Preparation of the ligand and its metal complexes 1-5

Egypt. J. Chem. 62, No. 3 (2019) 
for the complexation reaction with metal ion complexes. All of the newly synthesized metal complexes (1-5) were air and moisture stable (Table 1) at room temperature. They were prepared by the stoichiometric reaction of the corresponding metal salts and the respective ligand in the molar ratio M:L of 1:1. Physical measurements and analytical data of the complexes $1-5$ are given in Tables 1 and 2.

\section{IR spectra}

The characteristic bands of IR spectra of ligand and their metal complexes are reported in experimental section and in Table 2. The ligand possessed potential donor sites like azomethine linkage $(-\mathrm{C}=\mathrm{N})$ and methoxy group $\left(-\mathrm{OCH}_{3}\right)$ which have tendency to coordinate with the metal ions. The IR spectra of the ligand showed the peaks at 1591 and $1223 \mathrm{~cm}^{-1}$ due to vibration of $(\mathrm{C}=\mathrm{N})$ and $(\mathrm{C}-\mathrm{O}-\mathrm{C})$ respectively while the peaks at 2920 and $2990 \mathrm{~cm}^{-1}$ due to vibration of aliphatic and aromatic (C-H) [26]. The comparison of the IR spectra of Schiff base ligand with corresponding metal complexes gave a different mode of absorption in complexation of ligand with the metal ions. The $\mathrm{C}=\mathrm{N}$ stretch shows both a positive and negative shift on complexation. We have observed a positive shift of azomethine to higher frequency at (1593-1596) $\mathrm{cm}^{-1}$ for Nickel, Palladium and Silver complexes while a negative shift of azomethine to lower frequency at (1567, 1590) $\mathrm{cm}^{-1}$ for the other complexes representing the involvement of the azomethine- $\mathrm{N}$ in the complex formation. while, the methoxy groups $\left(\mathrm{O}-\mathrm{CH}_{3}\right)$ band originally appearing at $1223 \mathrm{~cm}^{-1}$ in the spectra of the ligands shifted to lower frequency at (1211-1221) $\mathrm{cm}^{-1}$ in spectra of metal complexes.
In all the metal complexes, a new band appeared at $511-515 \mathrm{~cm}^{-1}$ due to $v(\mathrm{M}-\mathrm{N})$ vibrations indicating the coordination of nitrogen of azomethine. While the bands at $420-472 \mathrm{~cm}^{-1}$ due to $v(\mathrm{M}-\mathrm{O})$ indicating the coordination of oxygen of methoxy group with the metal ions [28].

For $\mathrm{Ni}(\mathrm{II})$ and $\mathrm{Cu}(\mathrm{II})$ complexes Other bands ascribed negative OAc were detected at (1330 and 1427) $\mathrm{cm}^{-1}$ and (1342 and 1415) $\mathrm{cm}^{-}$ ${ }^{1}$, respectively, suggesting $v_{\mathrm{s}}$ and $v_{\mathrm{as}}$ carboxylic modes. The large difference between the $v_{\mathrm{s}}$ and $v_{\mathrm{as}}$ frequencies confirmed the coordination of acetate as a unidentate anion through the $\mathrm{C}-\mathrm{O}$ moiety of the carboxylic group [28].

\section{Mass spectra of the ligand}

The mass spectral data and fragmentation pattern of the Schiff base ligand clearly justify. the formation of the ligand possessing proposed structures and their bonding pattern. The spectra of molecular ion peak m/z 312 (Calcd. 312.39) of $\left[\mathrm{C}_{17} \mathrm{H}_{16} \mathrm{~N}_{2} \mathrm{O}_{2} \mathrm{~S}\right]^{+}$which loses a methyl group to give a fragment at $\mathrm{m} / \mathrm{z} 297$ of $\left[\mathrm{C}_{16} \mathrm{H}_{13} \mathrm{~N}_{2} \mathrm{O}_{2} \mathrm{~S}\right]^{+}$. The fragmentation pattern followed the cleavage of $\mathrm{C}_{8} \mathrm{H}_{5} \mathrm{NO}$ to give a fragment at $\mathrm{m} / \mathrm{z} 165$ of $\left[\mathrm{C}_{8} \mathrm{H}_{7} \mathrm{NOS}\right]^{+}$. Which cleaved to remove N-S giving a fragment at $\mathrm{m} / \mathrm{z} 121$ of $\left[\mathrm{C}_{8} \mathrm{H}_{9} \mathrm{O}\right]^{+}$which in turn loses $\mathrm{C}_{2} \mathrm{H}_{5} \mathrm{OH}$ to give to give a benzene fragment at $\mathrm{m} / \mathrm{z} 74$ of $\left[\mathrm{C}_{6} \mathrm{H}_{3}\right]$. Another pathway may be considered, in which the ligand cleaved to remove ethyl group to give a fragment at $\mathrm{m} / \mathrm{z} 283$ of $\left[\mathrm{C}_{15} \mathrm{H}_{11} \mathrm{~N}_{2} \mathrm{O}_{2} \mathrm{~S}\right]^{+}$. The fragmentation pattern followed the cleavage of $\mathrm{C}-\mathrm{O}$ to give a fragment at $\mathrm{m} / \mathrm{z} 255$ of $\left[\mathrm{C}_{14} \mathrm{H}_{11} \mathrm{~N}_{2} \mathrm{OS}\right]^{+}$as shown in fragmentation pattern of the ligand in Scheme 2 and Fig. 2.

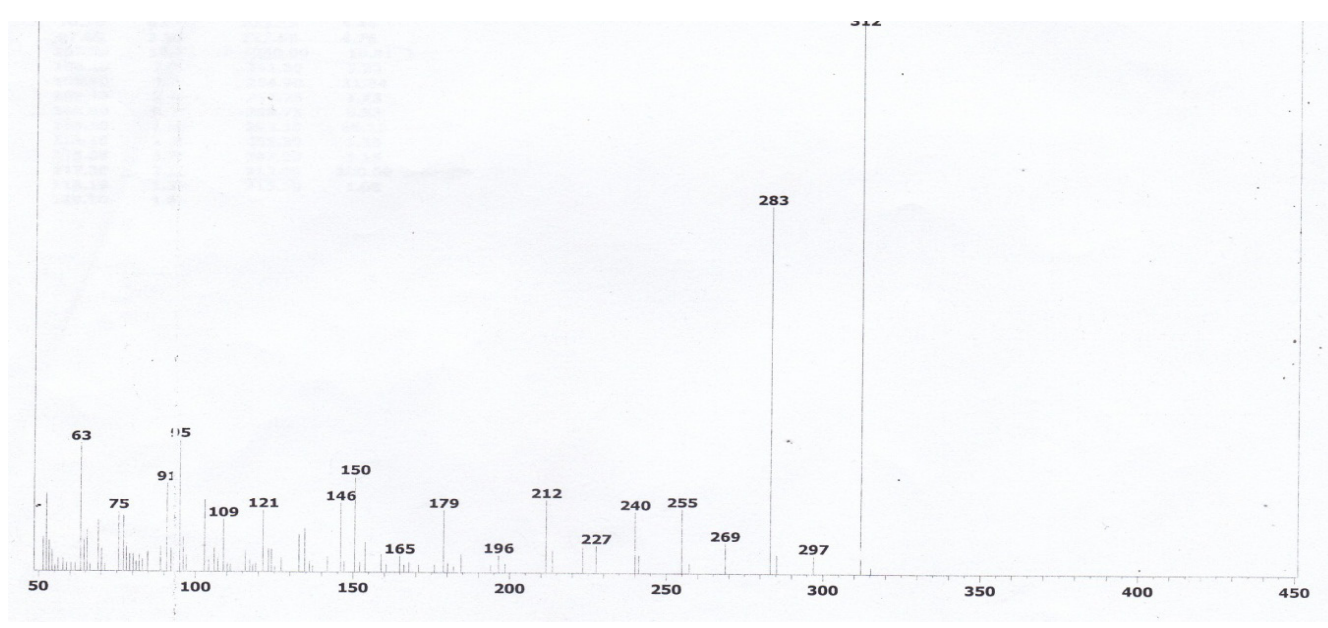

Fig. 2. Mass Spectra of the Ligand.

Egypt. J. Chem. 62, No. 3 (2019) 


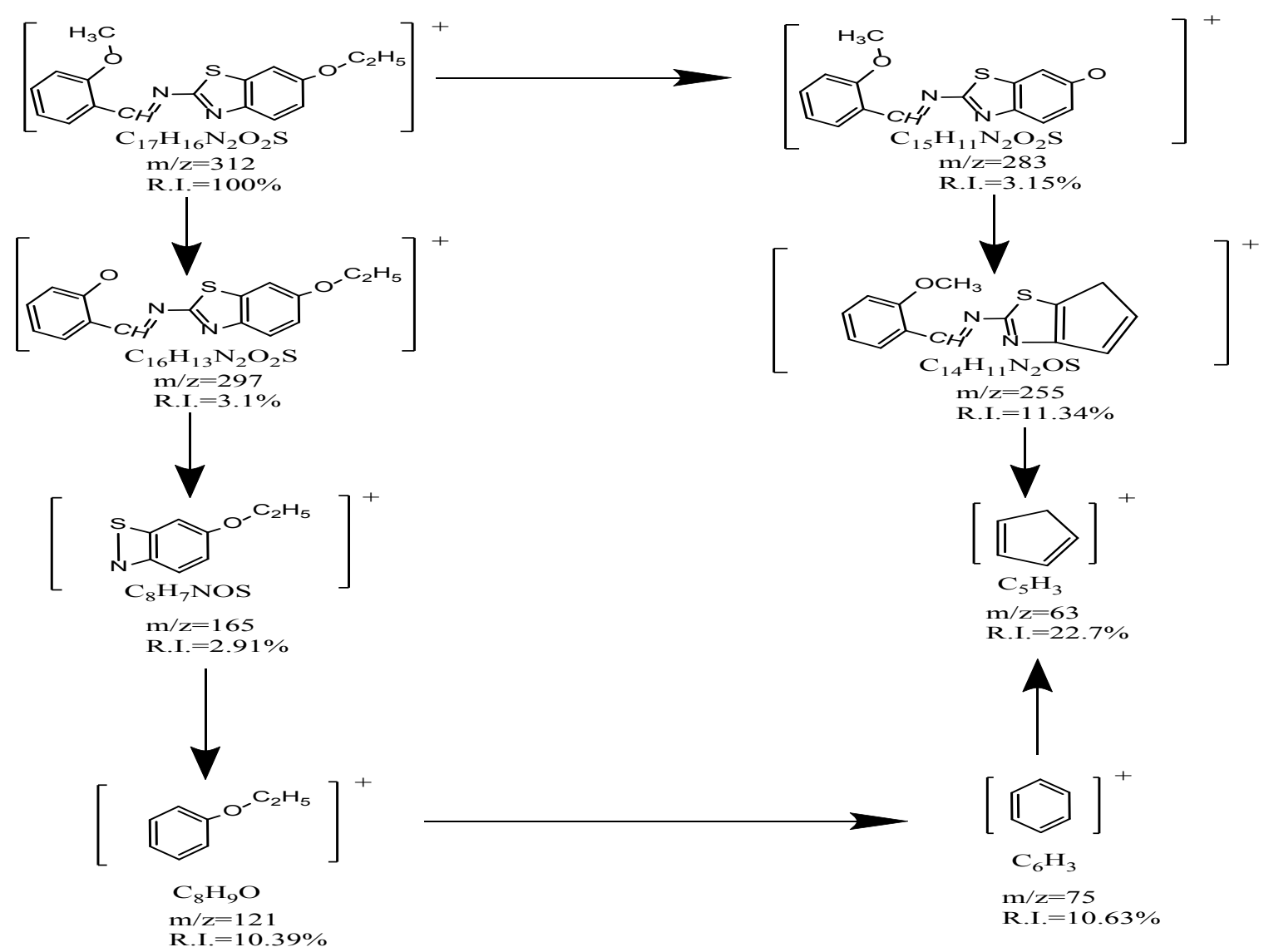

Scheme 2. Proposed mass fragmentation pattern of the ligand.

\section{Electronic spectra and magnetic properties}

The electronic spectral and magnetic moment (B.M) values of the ligand and its metal complexes at room temperature were of $\mathrm{Ni}(\mathrm{II}), \mathrm{Cu}(\mathrm{II})$, $\mathrm{Ag}(\mathrm{I}), \mathrm{Pd}(\mathrm{II})$ and $\mathrm{Au}(\mathrm{III})$ complexes are recorded in Table 2. The electronic spectra of ligand at $26738 \mathrm{~cm}^{-1}, 32468 \mathrm{~cm}^{-1}$ and $33222 \mathrm{~cm}^{-1}$ refers to $\mathrm{n}$ $\pi^{*}, \pi \longrightarrow \pi^{*}$ of $\mathrm{C}=\mathrm{N}$ and phenyl ring transitions, respectively. The electronic spectra of $\mathrm{Ni}$ (II) complex, the absorption band at $26624 \mathrm{~cm}^{-1}$ are assigned to the transition ${ }^{3} \mathrm{~T}_{1}(\mathrm{~F}) \longrightarrow{ }^{3} \mathrm{~T}_{1}(\mathrm{P})$ suggesting a tetrahedral geometry around $\mathrm{Ni}(\mathrm{II})$ ion with magnetic moment values 3.02 B.M for $\mathrm{Ni}(\mathrm{II})$ [29], for $\mathrm{Cu}$ (II) complex exhibited low-energy absorption band at $18450 \mathrm{~cm}^{-1}$ assigned to ${ }^{2} \mathrm{~B}_{2} \rightarrow{ }^{2} \mathrm{E}$ transition. The high-energy band at $23585 \mathrm{~cm}^{-1}$ is due to ligand to metal charge transfer (LMCT). On the basis of which a tetrahedral geometry is suggested for $\mathrm{Cu}(\mathrm{II})$ complex [30], the obtained magnetic moment value 1.95 B.M for $\mathrm{Cu}$ (II) complex are indicative of one unpaired electron per $\mathrm{Cu}$ (II) ion for $\mathrm{d}^{9}$-system suggesting tetrahedral structure. For
$\operatorname{Ag}(\mathrm{I})$ absorption band at $24390 \mathrm{~cm}^{-1}$ are assigned MLCT in a triagonal geometry confirmed by the diamagnetic properties [31]. In Pd(II) complex the two absorption bands at $26315 \mathrm{~cm}^{-1}$ and 27100 $\mathrm{cm}^{-1}$ are assigned respectively to the transitions ${ }^{1} \mathrm{~A}_{1 \mathrm{~g}} \longrightarrow{ }^{1} \mathrm{~B}_{1 \mathrm{~g}}$ and ${ }^{1} \mathrm{~A}_{\mathrm{lg}} \longrightarrow{ }^{1} \mathrm{E}_{1 \mathrm{~g}}$ and the diamagnetic properties suggested a squareplanar geometry around $\mathrm{Pd}(\mathrm{II})$ ion [32]. In $\mathrm{Au}(\mathrm{III})$ complex. The absorption band at $22448 \mathrm{~cm}^{-1}$ are assigned respectively to the transitions ${ }^{6} \mathrm{~A}_{1 \mathrm{~g}}$ ${ }^{6} \mathrm{E}_{\mathrm{g}}$ and the diamagnetic properties suggested an octahedral geometry around $\mathrm{Au}(\mathrm{III})$ ion.

\section{ESR Spectrum}

The ESR spectra of $\mathrm{Cu}(\mathrm{II})$ complex were recorded on X-Band at frequency (9.7) GHz under the magnetic field strength (3480) G, recorded at room temperature. The spectra of the complex exhibited a single anisotropic broad signal with hyper structure indicated the contribution of free acetate ligand with complex formation. The anisotropic spectrum of ESR $\mathrm{Cu}(\mathrm{II})$ showed a $\mathrm{g}_{\perp}>\boldsymbol{g}^{\|}$with the following values $\boldsymbol{g}^{\|}=2.08$ and Egypt. J. Chem. 62, No. 3 (2019) 
$\mathrm{g}_{\perp}=2.229$ for $\mathrm{Cu}(\mathrm{II})$ in which the ratio $\mathrm{g}_{\perp}>\boldsymbol{g}^{\prime \prime}>$ 2.0023 calculated for $\mathrm{Cu}$ (II) complex, suggest that the unpaired electron is localized in $\mathrm{d}_{\mathrm{x}-\mathrm{y}}{ }^{2}$ orbital $\mathrm{g}_{\perp}>\boldsymbol{g}_{/ /}$These values indicate that the ground state of $\mathrm{Cu}(\mathrm{II})$ is predominately $\mathrm{dx}^{2}{ }_{-}^{2}$, which suppose a tetrahedral [33]. The observed $\boldsymbol{g}^{\|}$value for $\mathrm{Cu}(\mathrm{II})$ complex is less than 2.3 , thus, indicating the bonds between the organic ligand and copper ion have a covalent character more than the ionic character (Table 1).

\section{Thermal analysis (TG)}

In the present investigation, the heating rates were suitably controlled at $10{ }^{\circ} \mathrm{C} \mathrm{min}-1$ under nitrogen atmosphere and the weight loss was measured from ambient temperature up to 30-900 ${ }^{\circ} \mathrm{C}$. The TG data of the thermal decomposition of the complexes are shown in Table 3, Fig. 3 and Scheme 3. The thermodynamic activation parameters of decomposition processes of dehydrated complexes namely activation energy $\left(\mathrm{E}^{*}\right)$, enthalpy $\left(\Delta \mathrm{H}^{*}\right)$, entropy $\left(\Delta \mathrm{S}^{*}\right)$ and Gibbs free energy change of the decomposition $\left(\Delta \mathrm{G}^{*}\right)$ are evaluated graphically by employing the CoatsRedfern relation [34] and Horowitz-Metzger [35]. Kinetic parameters for the first stages, calculated by employing the Coats-Redfern and HorowitzMetzger equations, are summarized in Table 4, together with the radii of metal ions. The results show that the values obtained by various methods are comparable. The kinetic data obtained with the two methods are in harmony with each other. The activation energy of $\mathrm{Ni}(\mathrm{II}), \mathrm{Cu}(\mathrm{II})$ and $\mathrm{Ag}$ (I) complexes is inversely proportional to ionic radius. The smaller size of the ions permits a closer approach of the ligand. Hence the mean of $E$ values in the three stages for the $\mathrm{Ag}(\mathrm{I})$ complex is higher than for the other complexes. The data are summarized in Table 4 . The activation energy was found to be 34.1, 29.05 and $76.04 \mathrm{KJmol}^{-1}$ in case of $\mathrm{Ni}(\mathrm{II})$ complex, 94.2, 29.04 and $20.59 \mathrm{KJmol}^{-1}$ in case of $\mathrm{Cu}$ (II) complex and 195.2, 640.29 and $42.63 \mathrm{KJmol}^{-1}$ in case of $\mathrm{Ag}(\mathrm{I})$ complex, for the first, second and third steps, respectively. The high values of the activation energies reflect the thermal stability of the complexes. The entropy of activation is found to have negative values in all the complexes therefore decomposition proceed spontaneously.

The thermogram of $\left[\mathrm{Ni}(\mathrm{L})(\mathrm{AcO})_{2}\right] 3 \mathrm{H}_{2} \mathrm{O}$ shows four decomposition steps; The first step at a temperature range of $(118-140){ }^{\circ} \mathrm{C}$ corresponds to the loss of $3 \mathrm{H}_{2} \mathrm{O}$ molecules $(9.9 \%)$. The second step at temperature ranges of (184-246)
${ }^{\circ} \mathrm{C}$ corresponds to the loss of two acetate (2AcO) $(22.32 \%)$. The third and fourth steps at temperature ranges of $(328-405,498-549){ }^{\circ} \mathrm{C}$ correspond to the loss of two organic parts with $\mathrm{MF}$ of $\left(\mathrm{C}_{7} \mathrm{H}_{3} \mathrm{NS}\right)$ $(27.5 \%)$ and $\left(\mathrm{C}_{10} \mathrm{H}_{13} \mathrm{~N}\right)(26.67 \%)$, leaving $\mathrm{NiO}$ $(14.26 \%)$ as a residue. The thermogram of $[\mathrm{Cu}(\mathrm{L})$ $\left.(\mathrm{AcO})_{2}\right] 3 \mathrm{H}_{2} \mathrm{O}$ shows four decomposition steps, the first step in the range of $(87-97){ }^{\circ} \mathrm{C}$ corresponds to the loss of $3 \mathrm{H}_{2} \mathrm{O}$ molecules $(9.58 \%)$. The second, third and fourth steps of decomposition at ranges of (160-185, 269-293 and 405-430) ${ }^{\circ} \mathrm{C}$, respectively, correspond to the loss of two acetate (2AcO) (21.8\%), ethoxy-benzothiazole with MF of $\left(\mathrm{C}_{8} \mathrm{H}_{8} \mathrm{NOS}\right)(32.3 \%)$ and the last organic part $\left(\mathrm{C}_{8} \mathrm{H}_{8} \mathrm{~N}\right)(21.76 \%)$, leaving $\mathrm{CuO}(14.12 \%)$ as a residue. The thermogram of $\left[\mathrm{Ag}(\mathrm{L}) \mathrm{NO}_{3}\right]$ shows three decomposition steps; The first step at a temperature range of $(67-180){ }^{\circ} \mathrm{C}$ corresponds to the loss of $\mathrm{NO}_{3}(13.2 \%)$. The second and third steps of decomposition at ranges of (207-248 and 470-542) ${ }^{\circ} \mathrm{C}$, respectively, correspond to the loss of ethoxy-benzothiazole with MF of $\left(\mathrm{C}_{8} \mathrm{H}_{8} \mathrm{NOS}\right)$ $(37.15 \%)$ and the last organic part $\left(\mathrm{C}_{8} \mathrm{H}_{8} \mathrm{~N}\right)(25.1$ $\%)$ leaving $\mathrm{Ag}_{2} \mathrm{O}(24.5 \%)$ as a residue. Thermal decomposition scheme of metal complexes $(1,2$ and 4) are shown in scheme 3.

\section{Biological activity. \\ Antimicrobial activity}

To contribute to the field of bioinorganic chemistry, the synthesized ligand and its $\operatorname{Ag}(\mathrm{I})$ complex were tested against bacterial and fungal strains by disc diffusion method. The microorganisms used in the present investigations included bacterial and fungal strains. Bacterial strains; Gram positive bacteria (Staphylococcus aureus (ATCC:6538) and Streptococcus mutans (ATCC:25175)), Gram negative bacteria (Klebsiella pneumonia (ATCC:4415), Pseudomonas aeruginosa (ATCC:27853) and Escherichia coli (ATCC:3008)) and fungal strains; Candida albicans (ATCC:10231). The results were compared with those of the standard drugs (Gentamicin for Gram positive bacteria, Ampicillin for gram negative bacteria and Nystatin for fungal strains) and calculated the diameter of inhibition zone for each by $\mathrm{mm}$.

\section{Antimicrobial activity of Ligand and its $\mathrm{Ag}(\mathrm{I})$ complex}

The antimicrobial activity of ligand and its $\operatorname{Ag}(\mathrm{I})$ complex against the bacterial and fungal strains were tested and evaluated. Table 5 shows the antimicrobial activity of ligand against the tested bacterial and fungal strains. Our results 

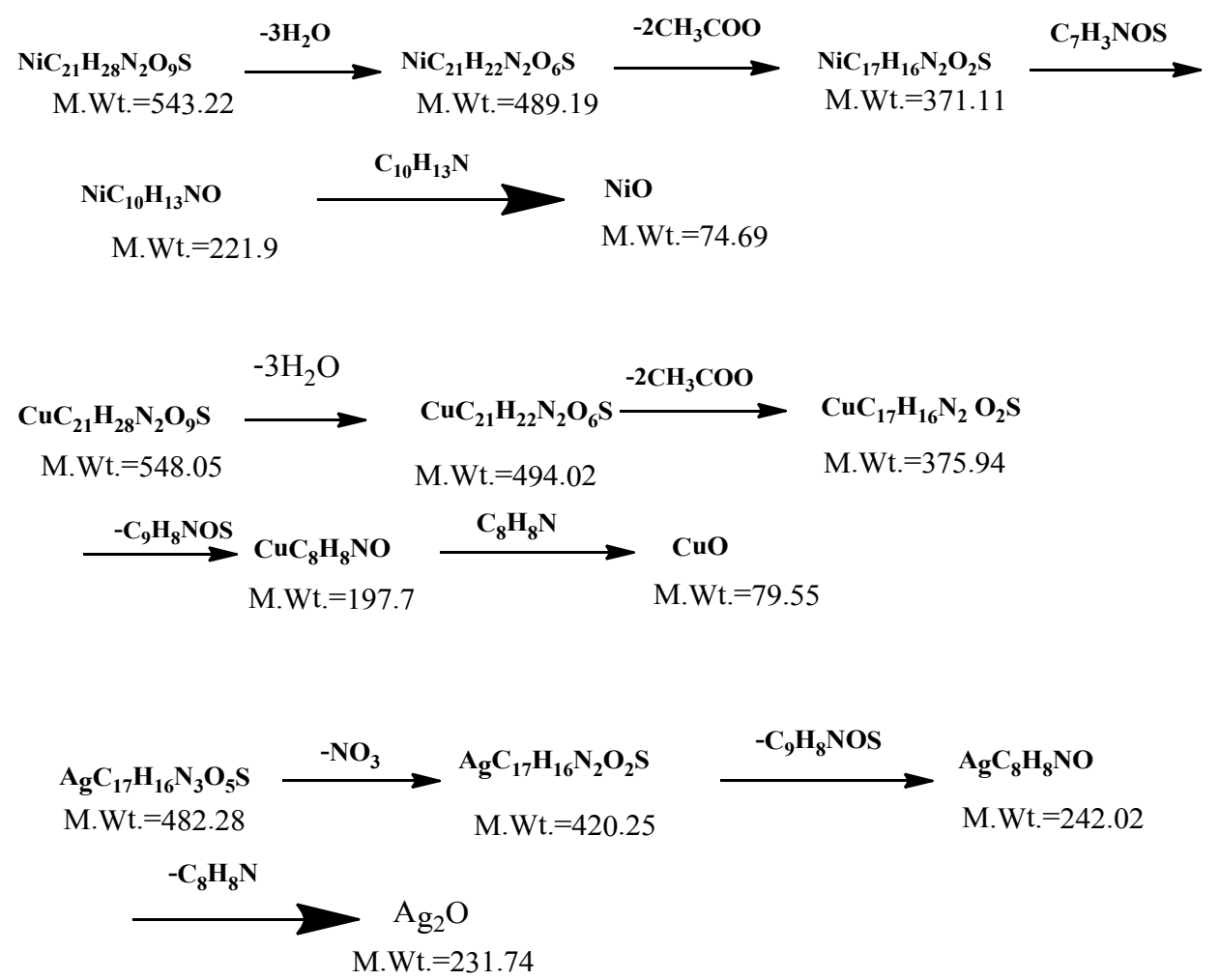

Scheme 3. Thermal decomposition of metal complexes (1, 2 and 4)

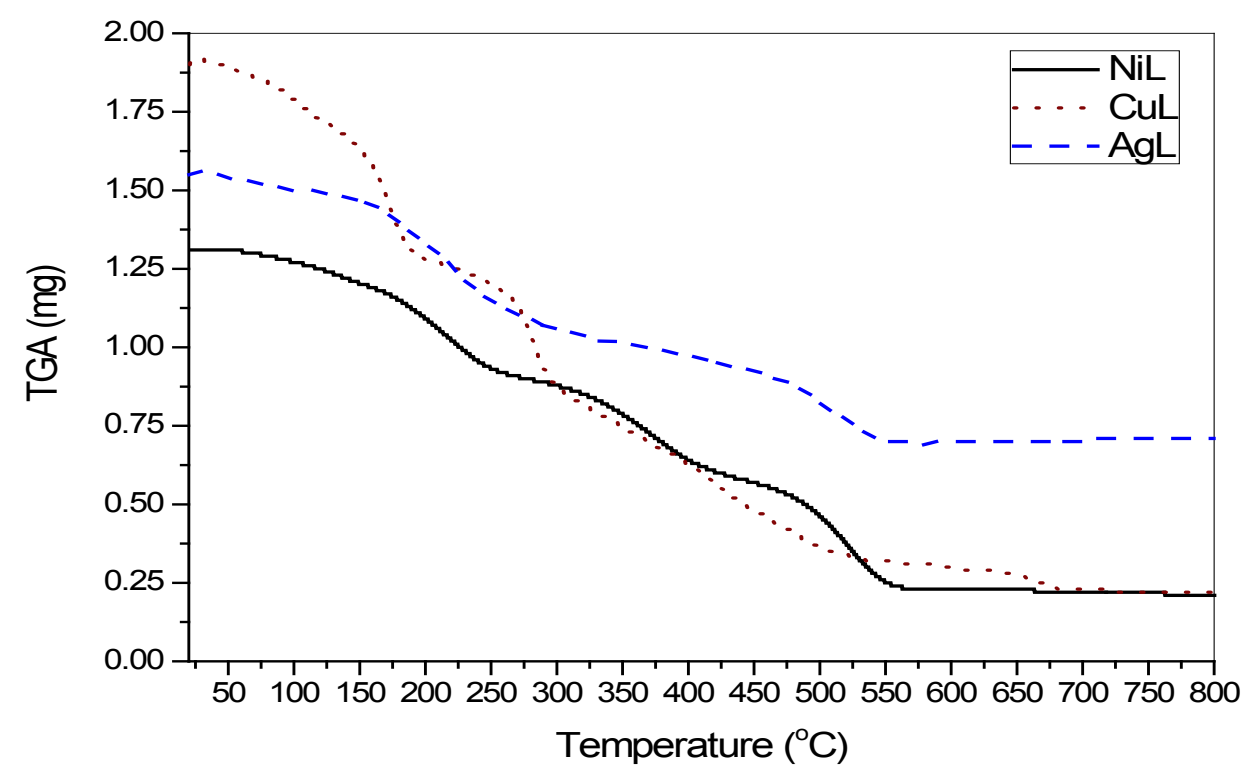

Fig. 3. Thermal analysis (TG) of $\mathrm{Ni}(1), \mathrm{Cu}(2)$ and $\mathrm{Ag}$ (4) complexes.

Egypt. J. Chem. 62, No. 3 (2019) 
showed no inhibition effect on the growth of the bacterial and fungal strains by the ligand excepted the effect on the growth of Klebsiella pneumonia (ATCC:4415) and Staphylococcus aureus (ATCC:6538) with inhibition zones 13.3 $\mathrm{mm}$ and $10.7 \mathrm{~mm}$, respectively. While the $\mathrm{Ag}(\mathrm{I})$ complex exhibited good antimicrobial activity against both bacteria (Gram-negative \& Grampositive bacteria) and fungal strains. It showed higher antibacterial activity against Pseudomonas aeruginosa (ATCC:27853) and Candida albicans (ATCC:10231) with inhibition zone 27.3 and 13.7 mm respectively, while appearance moderated to weak activity against Klebsiella pneumonia (ATCC:4415), Escherichia coli (ATCC:3008), Staphylococcus aureus (ATCC:6538), and Streptococcus mutans (ATCC:25175) with inhibition zone 18.7, 15.3, 13.7 and $11.7 \mathrm{~mm}$, respectively. Hence the antimicrobial activity after complexation with $\operatorname{Ag}(\mathrm{I})$ is enhanced as compared to that of the free ligand.

\section{Anticancer activity}

The Schiff base ligand, L and its Au(III) complex were evaluated for human anti-cancer activity against MCF-7 celles. The reported results in terms of $\mathrm{IC}_{50}$ value for ligand is $15.1 \mu \mathrm{g} /$ $\mathrm{ml}$ while for its gold complex $\mathrm{IC}_{50}$ value is 5.56 $\mu \mathrm{g} / \mathrm{ml}$ (Fig. 4). For comparison purposes, the cytotoxicity of cisplatin, as standard antitumor drug, was evaluated and produced $\mathrm{IC}_{50}$ value (7.22 $\mu \mathrm{g} / \mathrm{ml}$ ) under the same conditions, where $\mathrm{IC}_{50}$ is the concentration which can reduce the growth of cancer cells by $50 \%$. The results classify these compounds as chemotherapeutically significant. The rank order of potency as a function of chelated metal ion follows the order $\mathrm{L}<\mathrm{St}<\mathrm{Au}$ (III) against MCF-7 cancer cells. The data indicate that the in vitro $\mathrm{IC}_{50}$ value for $\mathrm{Au}(\mathrm{III})$ against the cell lines is lower than the Ligand and, even, the standard, the activity of ligand could be explained by the solubility effect as fairly good relationship could

TABLE 3. Thermal decomposition of the (1, 2 and 4) complexes.

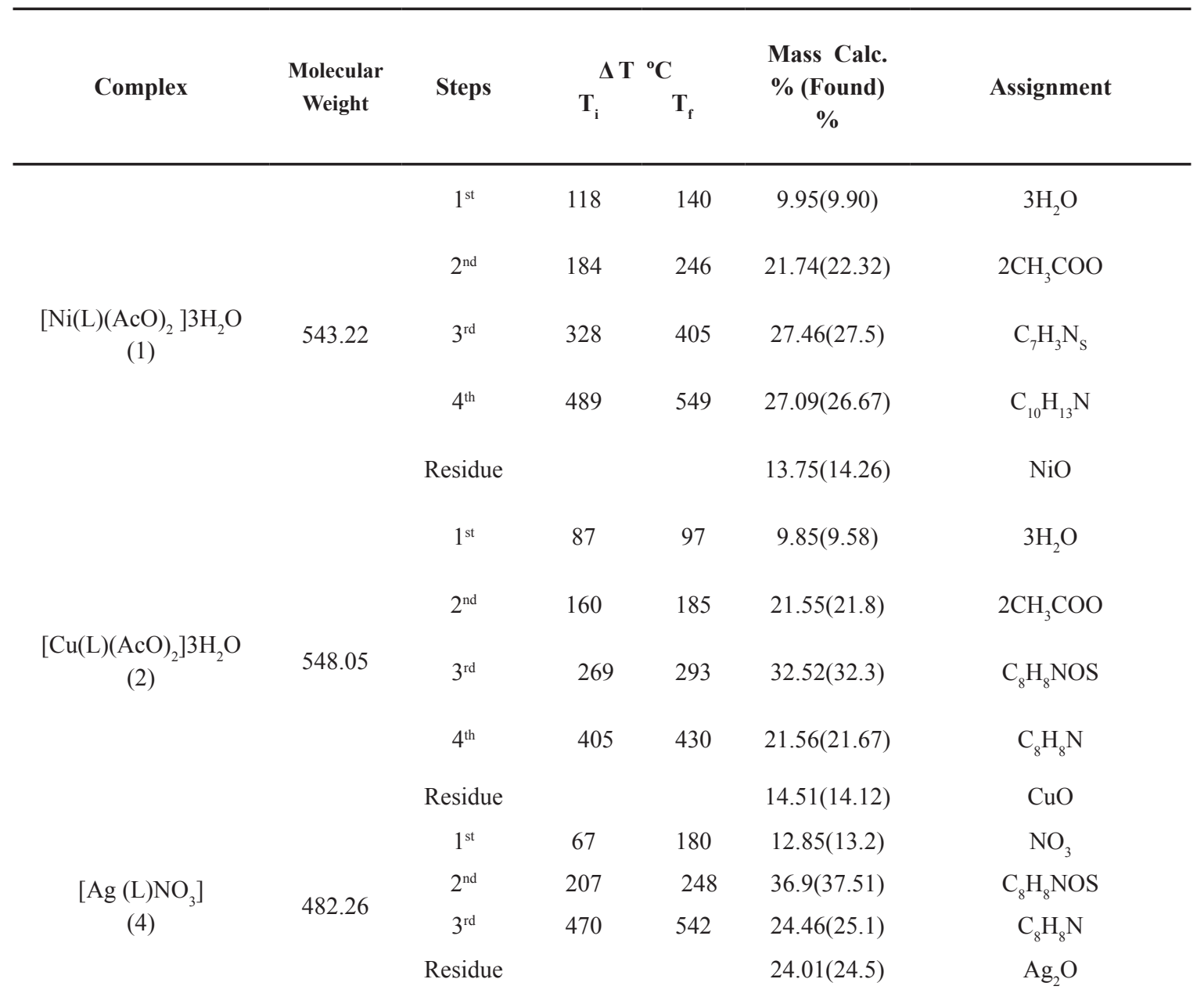


TABLE 4. Thermodynamic data of the thermal decomposition of the (1, 2 and 4$)$ complexes.

\begin{tabular}{|c|c|c|c|c|c|c|c|c|c|c|c|c|c|}
\hline \multirow[b]{2}{*}{$\begin{array}{c}\text { Compd. } \\
\text { No. }\end{array}$} & \multirow[b]{2}{*}{ Steps } & \multicolumn{6}{|c|}{ Coats Redfern } & \multicolumn{6}{|c|}{ Horowitz-Metzger } \\
\hline & & $\mathbf{R}^{2}$ & $\begin{array}{c}\mathbf{E}_{\mathrm{a}} \\
\mathbf{K J} \\
\mathbf{m o l}^{-1}\end{array}$ & $\begin{array}{l}\mathbf{A} \\
\mathbf{S}^{-1}\end{array}$ & $\begin{array}{c}\Delta \mathbf{S}^{*} \\
\mathbf{m o l}^{-1} \\
\mathbf{K}^{-1}\end{array}$ & $\begin{array}{c}\Delta \mathbf{H}^{*} \\
\mathbf{K J} \\
\mathbf{m o l}^{-1}\end{array}$ & $\begin{array}{c}\Delta \mathbf{G}^{*} \\
\mathbf{K J} \mathbf{m o l}^{-1}\end{array}$ & $\mathbf{R}^{2}$ & $\begin{array}{c}\mathbf{E}_{\mathrm{a}} \\
\mathbf{K J} \\
\mathbf{m o l}^{-1}\end{array}$ & $\begin{array}{l}A \\
S^{-1}\end{array}$ & $\begin{array}{c}\Delta \mathbf{S}^{*} \\
\mathbf{m o l}^{-1} \\
\mathbf{K}^{-1}\end{array}$ & $\begin{array}{c}\Delta \mathbf{H}^{*} \\
\mathbf{K J} \\
\mathbf{m o l}^{-1}\end{array}$ & $\begin{array}{c}\Delta \mathbf{G}^{*} \\
\mathbf{K J} \\
\mathbf{m o l}^{-1}\end{array}$ \\
\hline \multirow{4}{*}{ (1) } & $1^{\mathrm{st}}$ & 0.96 & 61.884 & $2.73 \times 10^{7}$ & -207.8 & 58.572 & 141.294 & 0.95 & 34.109 & $7.76 \times 10^{3}$ & -197 & 30.8 & 109.55 \\
\hline & $2^{\text {nd }}$ & 0.99 & 59.563 & $3.02 \times 10^{5}$ & -184.1 & 55.561 & 144.140 & 0.99 & 29.045 & $2.15 \times 10^{2}$ & -217.9 & 25.046 & 129.896 \\
\hline & $3^{\text {rd }}$ & 0.99 & 148.976 & $5.71 \times 10^{3}$ & -163.05 & 143.718 & 246.77 & 0.99 & 76.046 & $4.92 \times 10^{5}$ & -150.66 & 70.792 & 166.012 \\
\hline & $4^{\text {th }}$ & 0.99 & 168.654 & $2.65 \times 10^{10}$ & - & 162.098 & - & 0.99 & 78.676 & $2.5 \times 10^{4}$ & - & 72.125 & - \\
\hline \multirow{5}{*}{ (2) } & $1^{\mathrm{st}}$ & 0.94 & 11.816 & $1.3 \times 10^{-10}$ & -435.9 & 879.64 & 167.06 & 0.48 & 94.2 & $1.18 \times 10^{-2}$ & -285.3 & -2.075 & 101.5 \\
\hline & $2^{\text {nd }}$ & 0.97 & 67.331 & $1.9 \times 10^{-2}$ & -209.2 & 63.645 & 156.34 & 0.98 & 29.04 & $4.73 \times 10^{2}$ & -216.7 & 25.359 & 121.334 \\
\hline & $3^{\text {rd }}$ & 0.86 & 38.645 & $8.04 \times 10^{2}$ & -268.1 & 34.053 & 182.04 & 0.90 & 20.595 & 7.2 & -241.7 & 16.006 & 149.43 \\
\hline & $4^{\text {th }}$ & 0.96 & 85.603 & $6.7 \times 10^{5}$ & -220 & 79.9 & 230.88 & 0.97 & 41.547 & $\begin{array}{l}1.57 \\
\times 10^{2}\end{array}$ & -210.8 & 35.85 & 180.30 \\
\hline & $1^{\mathrm{st}}$ & 0.82 & 38.988 & $8.8 \times 10^{4}$ & -217.02 & 36.08 & 112.04 & 0.85 & 195.2 & $3.75 \times 10^{-2}$ & -305.08 & -957.5 & 105.82 \\
\hline \multirow[t]{2}{*}{ (4) } & $2^{\text {nd }}$ & 0.97 & 120.85 & $6.13 \times 10^{13}$ & -144.6 & 117.18 & 180.95 & 0.98 & 640.29 & $\begin{array}{l}1.52 \\
\times 10^{7}\end{array}$ & -135.55 & 60.363 & 120.141 \\
\hline & $3^{\text {rd }}$ & 0.99 & 88.75 & $3.99 \times 10^{8}$ & -138.07 & 84.644 & 152.7 & 0.99 & 42.64 & $\begin{array}{l}6.95 \\
\times 10^{3}\end{array}$ & -191.9 & 38.538 & 133.143 \\
\hline
\end{tabular}

TABLE. 5. The antimicrobial activity of the ligand and its $\operatorname{Ag}(\mathrm{I})$ complex.

\begin{tabular}{|c|c|c|c|}
\hline$\underbrace{\text { Sample }}_{\text {Microorganism }}$ & $\mathbf{L}$ & $\operatorname{Ag}(I)$ & Standard antibiotic \\
\hline Gram negative bacteria & & & Gentamicin \\
\hline $\begin{array}{l}\text { Escherichia coli } \\
\text { (ATCC:3008) }\end{array}$ & NA & $15.3 \pm 0.6$ & $35 \pm 0.5$ \\
\hline $\begin{array}{l}\text { Klebsiella pneumonia } \\
\text { (ATCC:4415) }\end{array}$ & $13.3 \pm 0.6$ & $18.7 \pm 0.5$ & $35 \pm 0.5$ \\
\hline $\begin{array}{l}\text { Pseudomonas aeruginosa } \\
\text { (ATCC:27853) }\end{array}$ & NA & $27.3 \pm 1.5$ & $30 \pm 0.5$ \\
\hline Gram positive bacteria & & & Ampicillin \\
\hline $\begin{array}{l}\text { Staphylococcus aureus } \\
\text { (ATCC:6538) }\end{array}$ & $10.7 \pm 0.6$ & $13.7 \pm 0.6$ & $30 \pm 0.1$ \\
\hline $\begin{array}{l}\text { Streptococcus mutans } \\
\quad(\text { ATCC:25175) }\end{array}$ & NA & $11.7 \pm 0.6$ & $35 \pm 0.5$ \\
\hline Fungi & & & Nystatin \\
\hline $\begin{array}{c}\text { Candida albicans } \\
\text { (ATCC:10231) }\end{array}$ & NA & $13.7 \pm 0.5$ & $20 \pm 0.5$ \\
\hline
\end{tabular}

Zone of inhibition is expressed in the form of mean \pm standard deviation $(\mathrm{mm})$. NA: No activity Well diameter $(6 \mathrm{~mm})$ $-100 \mu$ was tested. 


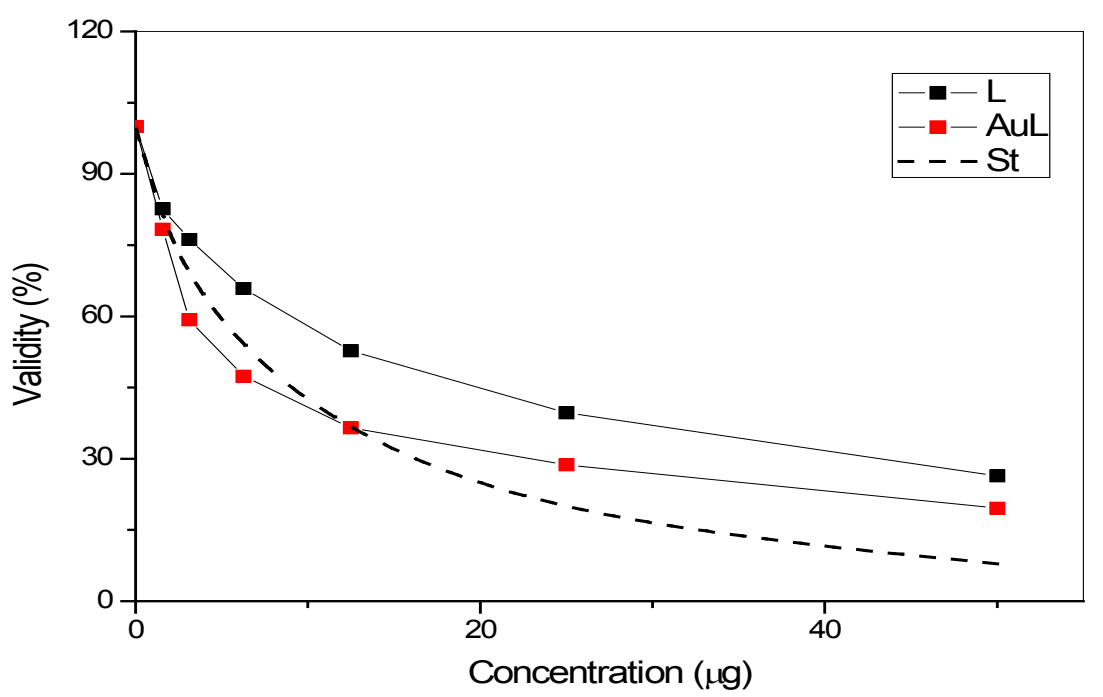

Fig. 4. Cytotoxicity of St. , L and Au(III)

be seen between activity and solubility of the compounds. The binding of a ligand to Au(III) ion enhances its activity[25] and gives $\mathrm{IC}_{50}$ value lower than the slandered under the same conditions.

\section{Conclusions}

The newly synthesized Schiff bases ligand obtained from condensation of 2-amino-6-ethoxybenzothiazole with 2-methoxy benzaldehyde using microwave technique act as bidentate ligand, which coordinated through the azomethine-N and methoxy-O to the metal ions; $\mathrm{Ni}(\mathrm{II}), \mathrm{Cu}(\mathrm{II})$, $\mathrm{Pd}(\mathrm{II}), \operatorname{Ag}(\mathrm{I})$ and $\mathrm{Au}(\mathrm{III})$. The thermal dehydration and decomposition of $\mathrm{Cu}(\mathrm{II}), \mathrm{Ni}(\mathrm{II})$ and $\mathrm{Ag}(\mathrm{I})$ complexes show elimination of water, acetate then organic content and MO remained as a residue. The activation energy of $\mathrm{Ag}(\mathrm{I})$ complex is higher than $\mathrm{Ni}(\mathrm{II})$ and $\mathrm{Cu}$ (II) as expected with decreasing in the radius. The cytotoxicity activities tested against (MCF-7) human tumor cell lines. The binding of a ligand to $\mathrm{Au}(\mathrm{III})$ ion enhances its activity to give $\mathrm{IC}_{50}$ value lower than the standared. The antimicrobial activity of ligand and its $\operatorname{Ag}(\mathrm{I})$ complex against the bacterial and fungal strains showed that the activity of the ligand after complexation with $\mathrm{Ag}(\mathrm{I})$ is enhanced as compared to that of the free ligand.

\section{References}

1. Paul, T., Anastas, and Warner, J. C., Green Chemistry Theory and Practice, Oxford University Press, (1998).

Egypt. J. Chem. 62, No. 3 (2019)
2. Manahan, S.E., Green Chemistry and The Ten Commadnents of Sustainability, manahans@ missouri.edu Chem. Char. Research, Inc. (2005).

3. Klinowski, J., Almeida Paz, F.A. and Rocha, J., Microwave-Assisted Synthesis of Metal Organic Frameworks, Dalton Trans. 40, 321-330 (2011).

4. Moorhead-Rosenberg, Z., Harrison, K.L., Turner, T. and Manthiram, A., A Rapid Microwave-Assisted Solvothermal Approach to lower-Valant Transition Oxides, Inorgan. Chem., 52, 13087-13093 (2013).

5. Booysen, I.N., Adebisi, A., Munro, O.Q. and Xulu, B., Ruthenium complexes with Schiff base ligands containing benzo(thiazole/imidazole) moieties: Structural, electron spin resonance and electrochemistry studies, Polyhedron, 73, 1-11 (2014).

6. Yeap, G.Y., Heng, B.T., Faradiana, N., Zulkifly, R., Ito M., Tanabe M. and Takeuchi, D., Synthesis, molecular structures and phase transition studies on benzothiazole-cored Schiff bases with their $\mathrm{Cu}(\mathrm{II})$ and $\mathrm{Pd}(\mathrm{II})$ complexes: Crystal structure of (E)-6-methoxy-2-(4-octyloxy-2hydroxybenzylideneamino)benzothiazole, Journal of Molecular Stracture, 1012, 1-11 ( 2012).

7. Chaudhary, P., Sharma P., Sharma, A. and Varshney, J., Recent advances in pharmacological activity of benzothiazole derivatives. International Journal of Current Pharmaceutical Research, 2(4), 5-11 (2010). 
8. Rana, A., Siddiqui, N. and Khan, S.A., Benzothiazoles: A new profile of biological activities, Indian Journal of Pharmaceutical Sciences, 69(1), 10-17 (2007).

9. Shi, D., Bradshaw, T., Wrigley, S., McCall, C., Lalieveld, P., Fichhtner, I. and Stevens, M., Synthesis of 2-(4-aminophenyl) benzothiazoles and evaluation of their activities against breast cancer cell lines in vitro and in vivo., Journal of Medical Chemistry, 39, 3375-3384 (1996).

10. Choi, S., Park, H., Lee, S., Kim, S., Han, G. and Choo, H., Solid phase combinatorial synthesis of benzothiazoles and evaluation of topoisomerase II inhibitory activity, Bioorganic \& Medicina Chemistry, 14, 1229-1235 (2006).

11. Bhuva, H.A. and Kini, S.G., Synthesis, anticancer activity and docking of some substituted benzothiazoles as tyrosine kinase inhibitors, Journal of Molecular Graphics and Modelling, 29, 32-37 (2010).

12. Gupta, S., Ajmera, N., Gautam, N., Sharma, R. and Gautam, D.C., Novel synthesis and biological activity study of pyrimido[2,1-b] benzothiazoles, Indian Journal of Chemistry, 48(B), 853-857 (2009).

13. Vedavathi, M., Somashekar, Sreenivasa, G.M. and Jayachandran E., Synthesis, characterization and antimicrobial activity of fluoro benzothiaozle incorporated with 1,3,4-thiadiazole, Journal of Pharmaceutical Sciences and Research, 2(1), 5363 (2010).

14. Sathe, B.S., Jayachandran, E., Jagtap, V.A. and Sreenivasa, G.M., Anthelmintic activity of newly synthesized moieties of fluoro benzothiazole Schiff's bases, Research Journal of Pharmaceutical, Biological and Chemical Sciences, 2(1), 510-515 (2011).

15. Sreenivasa, G.M., Jyachandran, E., Shivakumar, B., Jayaraj, K.K. and Kumar, V., Synthesis of bioactive molecule fluoro benzothiazole comprising potent heterocyclic moieties for anthelmintic activity, Pharmaceutical Science and Research, 1(2), 150157(2009).

16. Nagarjan, S., Crescenzo, G., Getman, D., Lu, H., Sikorski, J., Walker, J., McDonald, J., Houseman, K., Kocan, G., Kishore, N., Mehta, P., Shippy, C. and Blystone, L., Discovery of Novel Benzothiazole sulfonamides as potent inhibitors of HIV-1 Protease, Bioorganic \& Medicinal Chemistry, 11, 4769-4777(2003).
17. Hout, S., Azas, N., Darque, A., Robin, M., Giorgio, C., Gasquet, M., Galy, J. and David, P., Activity of benzothiazoles and chemical derivatives on Plasmodium falciparum, Parasitology, 129, 525542 (2004).

18. Delmas, F., Avellaneda, A., Giorgio, C., Robin, M., Clercq, E., David, P. and Galy, J.P., Synthesis And antileishmanial activity of (1,3- benzothiazol-2-yl) amino-9-(10H)-acridinone derivatives, European Journal of Medicinal Chemistry, 39, 685-690 (2004).

19. Venkatesh P. and Pandeya S.N., Synthesis, characterization and anti-inflammatory activity of some 2-amino benzothiazole derivatives, International Journal of Chem. Tech. Research, 1(4), 1354-1358 (2009).

20. Kaur, H., Kumar, S., Singh, I., Saxena, K.K. and Kumar, A., Synthesis, characterization and biological activity of various substituted benzothiazole derivatives, Digest Journal of Nanomaterials and Biostructures, 5(1), 67-76 (2010).

21. Siddiqui, N., Pandeya, S.N., Khan, S., Stables, J., Rana, A., Alam, M., Arshad, M. and Bhat, M., Synthesis and anticonvulsant activity of sulfonamide derivatives-hydrophobic domain, Bioorganic \& Medicinal Chemistry Letters, 17, 255-259 (2007).

22. Amnerkar, N. and Bhusari, K.P., Synthesis, anticonvulsant activity and 3D-QSAR study of some prop-2-eneamido and 1-acetyl-pyrazolin derivatives of aminobenzothiazole, European Journal of Medicinal Chemistry, 45, 149-159 (2010).

23. Pattan, S.R., Suresh, C.h., Pujar, V.D., Reddy, V.V.K., Rasal, V.P. and Koti, B.C., Synthesis and antidiabetic activity of 2-amino 5'(4sulphonylbenzylidine)-2,4-thiazolidinedione]-7chloro-6- fluuorobenzothiazole, Indian Journal of Chemistry, 44(B), 2404-2408 (2005).

24. Surya, K.D., Chen, L.H., Stebbins, J.L., Machleidt, T., Mehan, M., Dahl, R., Chen Yuan, H., Barile, E., Emdadi, A., Murphy, R. and Pellecchia, M., Discovery of 2-(5-nitrothiazol-2- ylthio)benzo [d]thiazoles as novel c-Jun N-terminal kinase inhibitors, Bioorganic \& Medicinal Chemistry, 17, 2712-2717(2009).

25. El alfy, H., Hassan, A., Shawky, E., Khattab, A. E. H. and Heakal B. H., Synthesis, Characterization and Biological Evaluation Studies of 4-((3-FormylEgypt. J. Chem. 62, No. 3 (2019) 
4-hydroxyphenyl) diazinyl) -N-(4-methyloxazol2-yl) Benzene Sulfonamide with $\mathrm{Cu}(\mathrm{II}), \mathrm{Ni}$ (II), $\mathrm{Zn}(\mathrm{II})$ and $\mathrm{Ag}(\mathrm{I})$ Using a Microwave Irradiation, Egyptian Journal of Chemistry, 61(4), 569-580 (2018).

26. Issa, R.M., Khedr, A.M. and Rizk, H., ${ }^{1} \mathrm{H}$ NMR, IR and UV/VIS Spectroscopic Studies of Some Schiff Bases Derived From 2-Aminobenzothiazole and 2-Amino-3- hydroxypyridine, Journal of The Chinese Chemical Society, 55, 875-884 (2008).

27. Scott, A.C. Laboratory control of antimicrobial therapy. In: Collee JG et al. eds. Practical Medical Microbiology, 13th Edition. Edinburgh: Churchill Livingstone, 161 (1989).

28. Ali, A.M, Ahmed, A.H., Mohamed, T.A. and Mohamed, B.H., Chelates and corrosion inhibition of newly synthesized Schiff bases derived from o-tolidine, Transition Metal Chemistry, 32, 461467 (2007).

29. Lever, A.P.B. Inorganic Electronic Spectroscopy, Theory and Applications, Elsevier, Amsterdam, (1984).

30. Hassan, A.M., Heakel, B.M., Kahela, T.M., Fouad, O.A. and Mohy Eldin A., Synthesis, characterization and inhibitory activity against breast carcinoma cells of a new azo-Ligand and its metal complexes, Journal of Chemical and Pharmaceutical Research, 8(5), 771-782 (2016).

31. Naeimi, H. and Moradian, M. Synthesis and characterization of nitroSchiff bases derived from 5-nitro-salicylaldehyde and various diamines and their complexes of $\mathrm{Co}(\mathrm{II})$, Journal of Coordination Chemistry, 62, 156-160 (2009).

32. Griffith, W.P. and Wickins, T. D. Journal of Chemical Society, (A), 400, 93 (1968).

33. Kivelson, D. and Neiman, R., ESR Studies on the Bonding of Copper Complexes, J. Chem. Phys., 35 , 149 (1961).

34. Coats, A.W. and Redfern, J.P., Kinetic Parameters From Thermogravimetric Data, Nature, 201, 68-69 (1964).

35. Horowitz, H.H. and Metzger, G., A New Analysis of Thermogravimetric Traces, Analytical Chemistry, 35(10), 1464-1468 (1963).

(Received 25/7/2018; accepted $11 / 10 / 2018)$

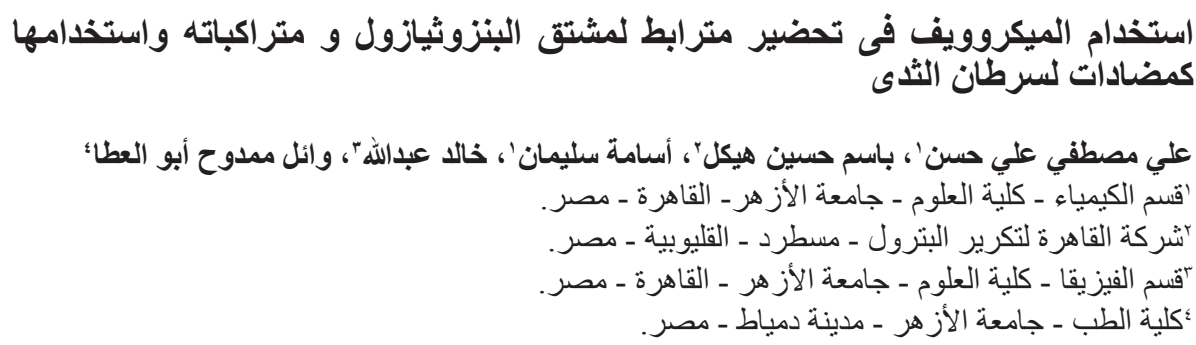

تم استخدام تقنية الميكروويف في تحضيردنر ابط (مشتق البنزوثيازول) وتحضير متر اكبات النحاس و النيكل

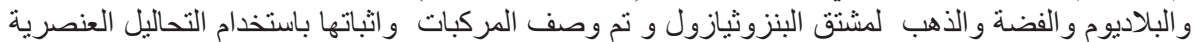

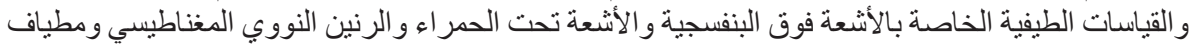

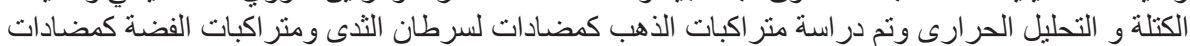

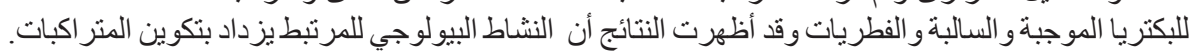

